Relations industrielles

Industrial Relations

\title{
Gorgeu, Armelle, René Mathieu et Michel Pialoux, Organisation du travail et gestion de la main-d'oeuvre dans la filière automobile
}

\section{Jean Gérin-Lajoie}

Volume 54, numéro 4, 1999

URI : https://id.erudit.org/iderudit/051278ar

DOI : https://doi.org/10.7202/051278ar

Aller au sommaire du numéro

Éditeur(s)

Département des relations industrielles de l'Université Laval

ISSN

0034-379X (imprimé)

1703-8138 (numérique)

Découvrir la revue

Citer ce compte rendu

Gérin-Lajoie, J. (1999). Compte rendu de [Gorgeu, Armelle, René Mathieu et Michel Pialoux, Organisation du travail et gestion de la main-d'oeuvre dans la filière automobile]. Relations industrielles / Industrial Relations, 54(4), 824-826. https://doi.org/10.7202/051278ar

Tous droits réservés (C Département des relations industrielles de l'Université Laval, 1999
Ce document est protégé par la loi sur le droit d'auteur. L’utilisation des services d'Érudit (y compris la reproduction) est assujettie à sa politique d'utilisation que vous pouvez consulter en ligne.

https://apropos.erudit.org/fr/usagers/politique-dutilisation/ 
d'utilisation de la stratégie de négociation concertée dans une organisation. Ce guide s'assoit sur deux postulats : la nécessaire relation de coopération entre des interlocuteurs patronaux et syndicaux, d'une part, et la qualité de la communication entre les interlocuteurs de même que l'animation de gardiens du processus de la négociation concertée, d'autre part. On pourrait être tenté de voir ce chapitre 6 comme une recette. Ce serait une grande erreur. Ce guide permet plutôt d'illustrer les éléments essentiels de la démarche proposée.

À titre de conclusion à cet ouvrage, les rédacteurs ont choisi de s'interroger sur l'avenir des nouvelles approches de négociation en relations du travail. Ils s'arrêtent d'abord sur l'évolution de ces nouvelles approches de négociation et identifient trois phases qui caractérisent l'implantation de celles-ci chez nous : la phase de découverte (1983-1993), celle de l'engouement (1993-1997), et la période de l'essoufflement depuis 1998.
Ils illustrent ensuite l'avenir de ces nouvelles approches en analysant l'entente de stabilité opérationnelle d'une durée de dix-huit ans signée en 1998 entre Alcan (Sécal) et la Fédération des syndicats du secteur aluminium (FSSA). Les rédacteurs terminent sur une note fort optimiste.

Somme toute, il s'agit d'un excellent ouvrage qui devrait être lu et analysé par tout participant, tout étudiant et tout observateur de la scène des relations du travail. Ce volume n'en est pas un de recettes ni un effort de vente d'une approche donnée. Il provoque la réflexion eu égard au monde changeant qui entoure les relations industrielles.

Il faut lever son chapeau devant un effort de concertation si bien réussi.

JEAN SEXTON

Département des relations industrielles Université Laval

\section{Organisation du travail et gestion de la main-d'œuvre dans la filière automobile \\ par Armelle GORGEU, René MATHIEU et Michel PIALOUX, Noisy-Le-Grand : Centre d'études de l'emploi, dossier 14, 1998, 134 p.}

Avec maîtrise, les auteurs atteignent l'objectif qu'ils se sont fixé. Celui-ci est l'examen de l'organisation du travail, de la gestion de la main-d'œuvre, et des relations professionnelles dans la filière automobile française. Lui-même, le mot " filière " est en rapport avec leur propos. Car la filière automobile, comme ils l'entendent, est faite des constructeurs, dénommés assembleurs en Amérique, puis des équipementiers spécialisés ou des fournisseurs de premier niveau, et enfin des fournisseurs de second niveau maillés diversement avec ceux du premier niveau ou avec les constructeurs.

L'ouvrage est pertinent et d'actualité en Amérique pour deux raisons. L'une est la croissance fulgurante et mondiale du maillage dans l'automobile, tel qu'en témoigne la vogue de vocables tels que
" assemblage modulaire ", "Blue Macaw " ou "Yellowstone". L'autre est le drame parallèle, et sans doute primordial, que vit l'industrie automobile américaine ; la séparation de Delphi d'avec General Motors; la redéfinition de General Motors ; le renouvellement de Ford ou de Daimler-Chrysler ; la visibilité accrue des usines mexicaines; ou encore l'implantation accrue des équipementiers japonais en Amérique qui approvisionnent les implants japonais en Amérique, tous pays confondus.

Le contexte, bien sûr, est celui d'une concurrence à la fois intense, croissante et mondialisée. Les survivants ne seront pas légion. Les exigences de la survivance seront dramatiques. D'où la question de recherche à laquelle tentent de répondre les auteurs: "Ces exigences 
entraînent-elles la diffusion d'un même mode de gestion de la main-d'œuvre dans la filière automobile? " Les recherches furent effectuées de 1996 à 1998. Les régions choisies furent le Nord, la FrancheComté, et Mulhouse. Une soixantaine d'entretiens ont été conduits, portant sur 36 établissements. La plasturgie et le travail des métaux sont bien représentés dans leur échantillon.

La première transformation observée par les auteurs est celle de l'organisation de la production et du travail. Ils en décrivent quatre aspects. Le premier est l'investissement en bâtiment, permettant de réorganiser la production et de répondre au juste-à-temps. Le second est la réorganisation du travail par la suppression des postes qui n'apportent pas de valeur ajoutée, par la mise en place d'îlots autonomes de production, et aussi par un management participatif comportant des systèmes de suggestions et la recherche de l'amélioration continue : le kaizen japonais. Le troisième aspect est le développement de la flexibilité du temps de travail : horaires postés ou disponibilité pour du temps supplémentaire. Le quatrième aspect est l'identité des acteurs de la diffusion des innovations : il s'agit des constructeurs automobiles eux-mêmes, des cabinets conseils associés à la filière automobile, ou de mouvements importants des cadres dirigeants dans les groupes d'équipement automobile.

La seconde transformation, selon les auteurs, est le développement des compétences par le recours au marché externe et à la formation. L'embauche de personnel permanent est très parcimonieuse et sélective. Tous les établissements de l'échantillon utilisent en permanence une main-d'œuvre ouvrière à statut précaire, en général intérimaire. Le diplôme constitue pour les employeurs un filtre, et ceux-ci essaient de minimiser leurs coûts de formation en prélevant les plus diplômés dans la file d'attente. Un nombre important d'emplois durables sont précarisés par le recours au personnel temporaire, au personnel en contrat à durée déterminée, ou aux intérimaires. La formation du personnel et l'évaluation des compétences individuelles sont étroitement axées sur les exigences de production propres à chaque entreprise, et donc sont peu transférables hors de l'entreprise. La reconnaissance de la qualification professionnelle, observent et déplorent les auteurs, est en voie d'être remplacée par la reconnaissance de la compétence individuelle.

La troisième transformation identifiée par les auteurs est celle des relations professionnelles et des pratiques salariales. Les quelques informations qu'ont pu obtenir les auteurs sur les relations professionnelles dans les usines étudiées les portent à conclure que, comme dans les entreprises françaises en général, la situation la plus courante est l'absence de contre-pouvoir syndical et de véritables négociations. Dans les régions étudiées, les traditions syndicales sont vivaces. Sauf exceptions, les usines enquêtées ont toutes des organisations syndicales, mais toutes ne sont pas revendicatives. Les directions d'entreprise préfèrent une coopération de type management participatif avec le personnel. Les innovations salariales observées sont notamment l'individualisation des salaires, les accords d'intéressement, la révision des classifications, mais, dans l'ensemble, elles semblent moins généralisées que les innovations organisationnelles. Leur absence peut s'expliquer par le poids du passé et la présence syndicale.

Les auteurs concluent leur ouvrage par un plaidoyer contre certaines des conséquences de la politique d'externalisation des constructeurs automobiles. Ils s'inquiètent en particulier du " clivage entre emplois de production classés non qualifiés et autres emplois, qui recouvre en grande partie le clivage emplois précaires/emplois permanents". Quant à la gestion de la production ou plus juste, ils se demandent : "peut-on laisser la précarité se banaliser à ce point? " lls s'inquiètent aussi de ce que les entreprises préfèrent, pour des emplois 
de production, former des jeunes sans expérience, plutôt que d'embaucher des personnes ayant déjà une expérience professionnelle, cherchant ainsi «à déstructurer les formes anciennes de culture ouvrière en cassant les collectifs ouvriers et, par-là, empêcher l'émergence des revendications collectives ".

JEAN GÉRIN-LAJOIE École des H.E.C. Montréal

\section{Trois usines mexicaines}

par Jean GÉRIN-LAJOIE, Montréal : École des hautes études commerciales, Centre d'études en administration internationale, 1999, 141 p., ISBN 2-9202-9671-X.

Students of industrial relations have tended to examine the impact of globalization on industrial relations in terms of linear views such as the "Race to the Bottom" in employment relations and labour standards. Jean Gérin-Lajoie in this innovative and important book examines the other side of the story: How do work relations actually work on the ground? What are the different perspectives of supervisors and workers? What are their levels of satisfaction? What are their expectations for the future?

The Golden Age of the post-war boom, rising living standards, expanding opportunities and the social safety net was based on about 20 countries comprising about 600 million people. The world economy is now comprised of 200 countries and 6 billion people. The hopes and prospects of success of workers in these three plants, as revealed by the author, give us critical indications of where we are going and what's next.

The research objective of the study is to examine the realities of social relationships in the context of large high tech industries. How is supervisory authority exercised? How is work organized? What different perceptions are held by supervisors and workers? How do these factors combine in the impact of N $\Lambda F T \Lambda$ and globalization?

The sites chosen for the case studies are all large industrial facilities characterized by the use of high tech manufacturing. The three factories are a GM auto plant, a Chrysler truck plant and an Imexsa steel mill. No claim is made that these plants or the results of the study can be taken as representative of all Mexican manufacturing, let alone Mexican society. All are part of large multinational corporations. None are Mexican owned. However, this does not subtract from their importance and the relevance of the author's insights.

The methodology employed was a large number (200) structured interviews with a representative sample of shopfloor and management employees, using a standard interview instrument. Chapters presenting results on the individual plants are followed by comparative analysis of the group as a whole.

The overall results and conclusions are focus on demographics, satisfaction levels, perspectives on personal futures and the perspectives on the future of Mexican society.

In regard to demographics, the two older factories, GM and Imexsa, as expected have older average age (29) and service workers ( 7 years). The Chrysler plant is much younger (23) and shorter term (23 months). The recruitment policies favour younger recruits (average 21 years). However, this must be understood in the context of the huge population of young people in Mexican society - over $50 \%$ under 18 .

The rate of married workers is also higher at the older plants : GM, 83\% and Imexsa, $76 \%$, compared to Chrysler at $54 \%$.

The educational level at all three plants is about the same, $10-11$ years of 